\title{
Do Exports to Developed Countries Stimulate Export Sophistication? Evidence from ASEAN Countries
}

\author{
Aditya Rangga Yogatama \\ Center for Strategic Issues Management \\ Ministry of Trade \\ Jakarta, Indonesia \\ ytc.yoga@gmail.com
}

\begin{abstract}
A country's sophistication of production and exports is important for economic transformation. Theoretically, the export destination influences country's export sophistication. One of the main mechanisms by which exports to developed countries can have a positive impact on production and export sophistication is skills upgrading. This paper aims to examine the effect of exports to developed countries on the export sophistication of ASEAN countries and relatively shows Indonesia's position towards other ASEAN countries in terms of export sophistication. The method we used is fixed effect panel data model by using the UNCTAD's index of comparative diversification vis-a-vis developed countries as dependent variable, which measures the similarity of exports with developed countries' exports. Empirical results show that higher share of exports to developed countries are significantly associated with higher export sophistication, but there are diminishing returns to this effect. The results also show that the Indonesia's export sophistication is relatively low compared to some other ASEAN countries, which is still below Malaysia and Thailand. This paper suggests that the Indonesian government needs to encourage Indonesian industries to target developed countries in order to enhance their productivity and product quality that lead to capability in exporting to the developed countries, which in turn will increase Indonesia's exports in general.
\end{abstract}

Keywords-Destination of exports; Export sophistication; ASEAN

\section{INTRODUCTION}

Production sophistication is generally associated with productivity, which in turn can lead to higher wages and income and increased welfare. Therefore, product and export sophistication is important for the economic transformation of a country [1]. In addition, there is a relationship between export destination and export sophistication, which means that industries that export to developed countries are more sophisticated in production and exports [2].

One of the main mechanisms by which exports to developed countries can have a positive impact on production and export sophistication is skills upgrading [3]. First, exporting to developed countries will lead firms to improve their skills, cause sophistication to increase [4] [2] [5]. Developed countries need skill-intensive quality improvements. Second, exporting to developed countries requires services such as distribution, transportation, advertising, and intensive activities in skilled labor [6] [7]. Developed countries need skill-intensive products and services. Finally, what is referred to as "learning by exporting" [8] [9]. Firms that export more will learn more. However, learning by exporting does not necessarily encourage upgrading or export sophistication skills, because the countries may specialize in low-skill-labor-internal products.

A number of studies have explored the relationship between trade and export sophistication. A number of factors were found to affect export sophistication including FDI, trade liberalization, institutional quality, human capital, technology, infrastructure, and financial development [10] [11] [12] [13] [14] [15] [16]. Anand \& Mishra (2012) found that educated labor, external liberalization, and information flows are important prerequisited for export sophistication. Iwamoto \& Nabeshima (2013) found that FDI inflows correlate positively with export diversification and export sophistication. Zhu \& $\mathrm{Fu}$ (2013) found that export sophistication is enhanced by capital deepening, engagement in knowledge creation, transfers via investment in education and R\&D and FDI and imports. Weldemicael (2012) found that FDI has a positif effect on export sophistication, and the effect is greater in countries with low institutional quality.

Based on the similarity of exports with developed countries'exports (SIMDEV), the export sophistication of ASEAN countries on average is relatively high, which is above 80 [3]. During the period 1995-2010, the export sophistication of ASEAN countries on average showed an increasing trend, from 80.77 in 2015 and reached 82.29 in 2010 (Fig. 1).

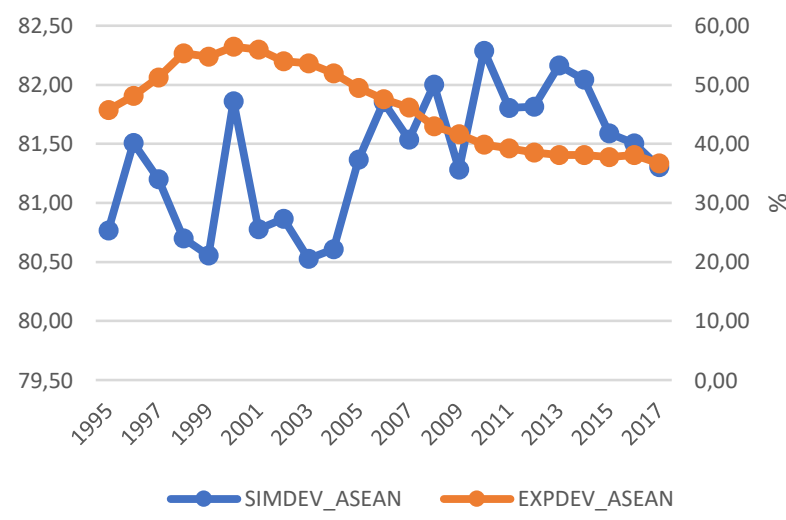

Source: UNCTAD Stat

Fig 1. ASEAN countries' export sophistication index and share of ASEAN countries' export to the developed countries, 1995-2017 
However, during the period of 2011-2017 ASEAN export sophistication tended to decline and be below 81.3 in 2017. On the other hand, the share of ASEAN exports to developed countries (EXPDEV) also tended to decline, from $56.45 \%$ in 2000 and became only 36.68 in 2017 . This shows a shift in different trade strategies in ASEAN, especially after the global economic crisis of 1997-1998, from concentration to diversification exports to new markets.

Among ASEAN countries, Thailand has the highest export sophistication value in 2017, amounting to 94.19 , followed by Malaysia (90.05), Singapore (88.25), Vietnam (84.42), Indonesia (84, 24), and Phillipines (84.05) (Fig. 2).

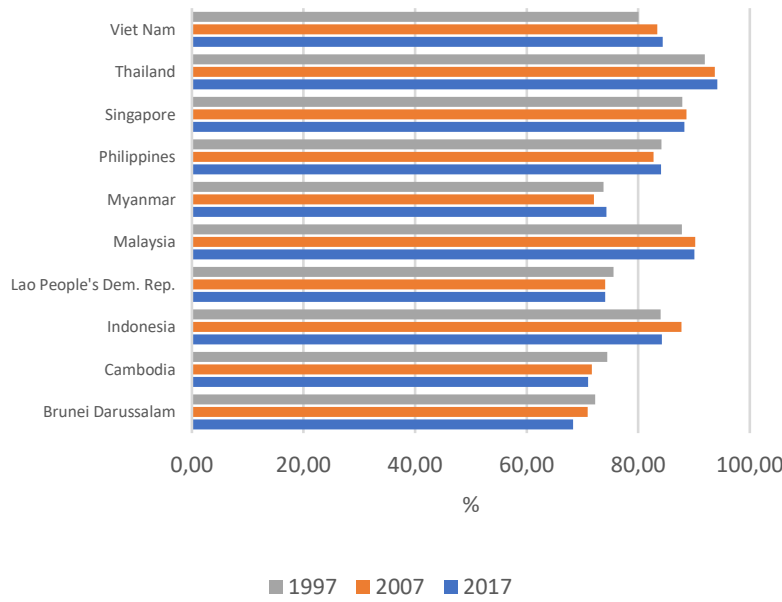

Source of data: UNCTAD Sta Fig 2. ASEAN countries'export sophistication index, 1997, 2007, and 2017

Furthermore, considering the share of exports to developed countries, Cambodia is the ASEAN country with the largest share with 73.76 in 2017, followed by Vietnam (50.83) and Phillipines (46.02) (Fig 3). Meanwhile, the share of Indonesia's exports to developed countries is only 33.88 .

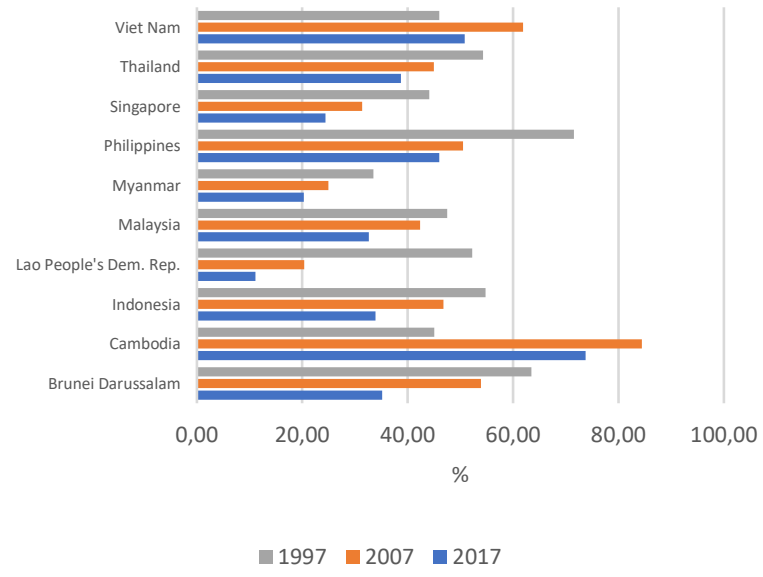

Source of data: UNCTAD Stat

Fig 3. Share of ASEAN countries' export to the developed countries, 1997, 2007, and 2017

Fig. 4 gives an overview of the export sophistication and the share of exports to developed countries for each ASEAN country in 2017. It can be seen that countries that have a share of exports to developed countries immediately have high export sophistication. Cambodia is the country with the highest export share compared to other ASEAN countries, reaching 73.76, but Cambodia's export sophistication value is only 71.05 or only slightly better than Brunei Darussalam. On the other hand, Thailand is the country with the highest export sophistication value in ASEAN, with a value of 94.19, but the share of exports to developed countries in Thailand is only $38.71 \%$.

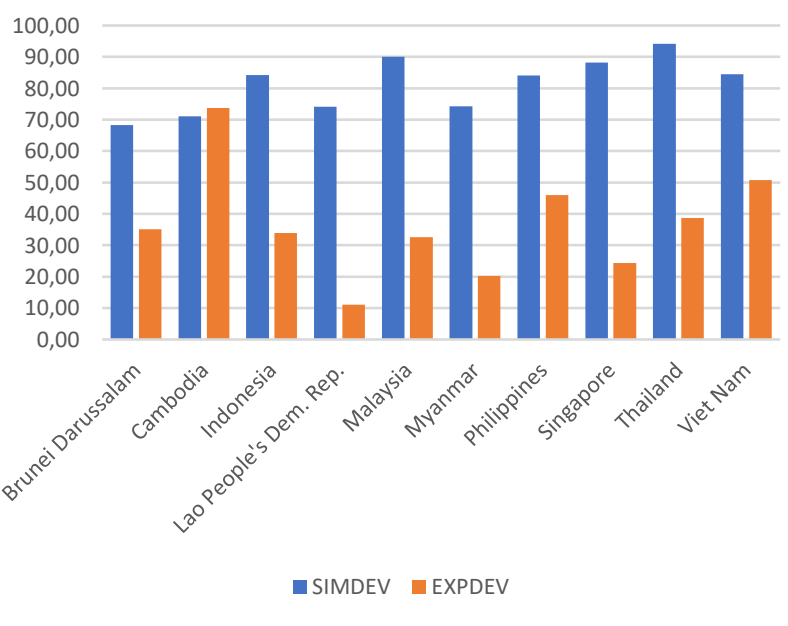

Source of data: UNCTAD Stat

Fig 4. Export sophistication index and share of export to the developed countries by ASEAN countries, 2017

This paper aims to test whether exports to developed countries affect the export sophistication of ASEAN countries during the period 2001-2017. Myanmar is excluded from the sample due to data availability on capital formation, FDI inflows and trade openness in the earlier period. Utilizing the time-fixed effect model estimation method of panel data, this study found. that exports to developed countries are seen to increase export sophistication but there are diminishing returns in this influence. This finding is in line with previous research by Baliamoune-Lutz which saw the effect of exports to developed countries on export sophistication of developing countries [3].

\section{METHODS}

\section{A. Model}

The equations used in this study are as follows:

$S_{I M D E V_{i t}}=\beta_{0}+\beta_{1} E X P D E V_{i t}+\beta_{2}$ GFCAP $_{i t}+$ $\beta_{3} F_{i t}+\beta_{4} O P E N_{i t}+\beta_{5} G O V_{i t}+\beta_{6} E X P D E V S Q_{i t}+$ $\beta_{7}$ GFCAPSQ $_{i t}+\beta_{8}$ FDISQ $_{i t}+\beta_{9}$ OPENSQ ${ }_{i t}+$ $\beta_{10}$ GOVSQ $_{i t}+\mu_{t}+\varepsilon_{i t}$

where SIMDEV is an indicator of export sophistication in country $i$ at time t. SIMDEV refers to export sophistication by Baliamoune-Lutz (2019) uses the UNCTAD's index of comparative diversification vis-a-vis developed countries, which measures export similarity with developed economies' products [3]. This research uses SIMDEV index of export sophistication rather than EXPY index of export sophistication because EXPY index has a limitation in that it 
does not taken into account the quality differences within a product category thus causing the overvaluation of EXPY of low-income countries [3] [16].

The determinant of export sophistication in this model includes export share to developed countries (EXPDEV), gross fixed capital formation as percentage of GDP (GFCAP), FDI inflow as percentage of GDP (FDI), trade opennes (OPEN), and average governance indicators (GOV). The equation includes the square form of each independent variables (EXPDEVSQ, GFCAPSQ, FDISQ, OPENSQ, and GOVSQ) to see whether there is a nonlinear relationship to the dependent variable.

In general, there are two methods for measuring the export sophistication of a country. First, export sophistication (EXPY) index by Hausman et al (2007) [1]. EXPY measures the average income associated with a countries' export bundles [14]. Product's sophistication defined as the tradeshare wighted average of income per capita of all the countries exporting this product, where the weights are each countries' export shares of world exports [17]. When a developing country exports products similar to products exported by developed countries, the EXPY value will increase. Second, export sophistication (SIMDEV) index by Baliamoune-Lutz (2019) uses the UNCTAD's index of comparative diversification vis-a-vis developed countries, which measures export similarity with developed economies' products. This index is an application of the export similarity index (ESI) proposed by Schott (2008) as follows

$$
S_{(a b)}=\left\{\sum_{i} \operatorname{Minimum}\left[X_{i}(a), X_{i}(b) 100\right]\right\}
$$

where $\mathrm{S}$ is the same pattern of exports of countries a and countries $b$. If the export pattern of country a is the same as the export pattern of country $b$, then the index will show a value of 100 [3] [18].

\section{B. Data}

This study uses data from 9 ASEAN countries, namely Brunei Darussalam, Cambodia, Indonesia, Malaysia, Lao PDR, the Phillipines, Singapore, Thailand and Vietnam. Myanmar is not included in the model due to data limitations on capital formation, FDI inflows and trade openness.

Export sophistication and export share to developed countries data are sourced from UNCTAD Statistics. As control variables: capital formation, FDI inflows and trade openness data are sourced from the World Development Indicator, World Bank, and governance data sourced from the Worldwide Governance Indicator, World Bank.

\section{Estimation Strategy}

The Equation (1) estimated by time-fixed effect model panel data. This estimation strategy can be chosen assuming that there are unobserved effects that differ between times rather than between units which have an impact on the dependent variable.

\section{RESULTS AND DISCUSSION}

Table I shows the descriptive statistics of the variables used in this study. The average of export sophistication in ASEAN countries (without Myanmar) during the period 20012017 is 82,23. This indicates that the export patterns of
ASEAN countries have approached developed countries. The average share of exports of ASEAN countries to developed countries is only 47,118 . This indicates that the exports of ASEAN countries tend to be diversified.

\begin{tabular}{lcllll}
\multicolumn{1}{c}{ TABLE I. } & \multicolumn{4}{c}{ DESCRIPTIVE STATISTICS } \\
\hline Variable & Obs & Mean & Std.Dev. & Min & Max \\
\hline SIMDEV & 153 & 82.23 & 7.945 & 68.35 & 94.24 \\
EXPDEV & 153 & 47.118 & 16.556 & 10.5 & 86.28 \\
GFCAP & 153 & 24.8 & 5.585 & 10.47 & 39.46 \\
FDI & 153 & 5.447 & 5.886 & -1.86 & 26.52 \\
OPEN & 153 & 140.045 & 92.301 & 37.42 & 441.6 \\
GOV & 153 & -.104 & .752 & -1.31 & 1.62 \\
- & & &
\end{tabular}

Table II shows that the share of exports to developed countries has a positive and significant effect on export sophistication. This means that the greater the share of exports to developed countries, the higher the export sophistication of the country. However, the negative and significant sign of the form of the square of the share of exports to developed countries shows that there is a turning point in the influence of the share of exports to developed countries on export sophistication from positive to negative. This finding is in line with the findings of Baliamoune-Lutz (2019).

TABLE II. TRADE WITH DEVELOPED COUNTRIES (EXPDEV) AND EXPORT SPOHISTICATION (SIMDEV). FIXED EFFECT ESTIMATES.

SIMDEV

\begin{tabular}{|c|c|}
\hline EXPDEV & $\begin{array}{l}0.517 \text { *** } \\
(4.13)\end{array}$ \\
\hline GFCAP & $\begin{array}{l}3.906^{* * * *} \\
(6.76)\end{array}$ \\
\hline FDI & $\begin{array}{l}-0.604 * \\
(-2.03)\end{array}$ \\
\hline OPEN & $\begin{array}{l}0.0512 * \\
(2.28)\end{array}$ \\
\hline GOV & $\begin{array}{l}-2.235^{*} \\
(-2.21)\end{array}$ \\
\hline EXPDEVSQ & $\begin{array}{l}-0.00701 \text { *** } \\
(-5.37)\end{array}$ \\
\hline GFCAPSQ & $\begin{array}{l}-0.0781 * * * \\
(-6.88)\end{array}$ \\
\hline FDISQ & $\begin{array}{l}0.0309^{*} \\
(2.58)\end{array}$ \\
\hline OPENSQ & $\begin{array}{l}0.0000147 \\
(0.28)\end{array}$ \\
\hline GOVSQ & $\begin{array}{l}-6.431 * * * \\
(-4.94)\end{array}$ \\
\hline _CONS & $\begin{array}{l}26.10 * * * \\
(3.43)\end{array}$ \\
\hline $\mathrm{N}$ & 153 \\
\hline $\mathrm{R}$-sq & 0.723 \\
\hline Adj. R-sq & 0.666 \\
\hline
\end{tabular}

$\mathrm{t}$ statistics in parentheses $* \mathrm{p}<0.05, * * \mathrm{p}<0.01, * * * \mathrm{p}<0.001$ 
Gross fixed capital formation and its squared form are also statistically significant, which indicates an inverted-U effect on export sophistication. This means that the greater the intensity of capital, the higher the export sophistication of the country. This finding is similar to Zhu and Fu (2013). In contrast, FDI and its squared form are also statistically significant and show U-shaped impacts on export sophistication. FDI which had a negative effect initially because the benefits received by ASEAN countries from FDI from developed countries were still limited in some sectors, as happened in Africa [19]. Trade openness has a positive and significant influence on export sophistication, while governance quality actually shows a negative and significant influence.

\section{CONCLUSION AND POLICY RECOMMENDATION}

This study investigates whether exports to developed countries stimulate product sophistication of ASEAN countries. The estimation results of fixed effect model suggest that exports to developed countries are seen to increase export sophistication but there are diminishing returns in this effect. This finding is in line with previous research by BaliamouneLutz (2019) which saw the effect of exports to developed countries on export sophistication of developing countries [3]. In addition, the same effect also occurs in groo fixed capital formation where there is an inverted-U pattern of the effect of gross fixed capital formation on export sophistication.

From this study, there are at least two recommendations for policy direction that can be taken. First, even though the diversification of exports to non-traditional markets is a strategic policy in the period of global uncertainty, it is important to target the markets of developed countries in order to improve export sophistication. Export sophistication, which means higher quality of existing products, will make exports more competitive and bring substantial benefits to developing countries in terms of economic growth [20]. The government needs to encourage industries to target the markets of developed countries so that upgrading skills occur. Upgrading skills will encourage increased quality and value added of export products and in turn increase overall export value. Second, the government needs to support industries in order to improve export sophistication by providing facilities as much as possible for industries and consistently maintain open trade policies.

\section{ACKNOWLEDGMENT}

This research was supported by Trade Analysis and Development Agency, Ministry of Trade of The Republic of Indonesia.

\section{REFERENCES}

[1] R. Hausman, J. Hwang, \& D. Rodrik "What you export matter" Journal of Economic Growth, 12(1), 2007, pp. 1-25.

[2] I. Brambilla, N. Depetris-Chauvin, \& G. Porto "Wage and employment gains from exports: Evidence from developing countries" Working papers 2015-28, CEPII Research Center, 2015.

[3] M. Baliamoune-Lutz "Trade sophisticatio in developing countries: Does export destination matter?" Journal of Policy Modelling, 41, 2009, pp. 39-51.

[4] E. Verhoogen "Trade, quality upgrading and wage inequality in the Mexican manufacturing sector" Quarterly Journal of Economics, 123(2), 2008, pp.489-530.
[5] N.A. Rankin \& V. Schoer "Export destination, product quality and wages in middle-income country: The case of South Africa" Review of Development Economics, 17(1), 2013, pp.64-73.

[6] C. Arkolakis "Market penetration costs and the new consumers margin in international trade" Journal of Political Economy, 118(6), 2010, pp.1151-1199.

[7] K. Matsuyama "Beyond icegergs: Toward a theory of biased globalization" The Review of Economic Studies, 74, 2007, pp. 237253.

[8] P. Bastos \& J. Silva “The quality of firm's exports: Where you export to matters" Journal of International Economics, 82(2), 2010, pp.99-111.

[9] K. Manova \& Z. Zhang "Export prices across firms and destinations" Quarterly Journal of Economics, 127(1), 2012, pp. 379-436.

[10] R. Anand, S. Mishra, N. Spatafora "Structural transformation and the sophistication of production" International Monetary Fund WP/12/59, 2012.

[11] A.M. Fernandes \& C. Paunov "Does trade stimulate product quality upgrading?" Canadian Journal of Economics, 46(4), 2013, pp. 12321264.

[12] T. Harding \& B.S. Javorcic "FDI and export upgrading" Economic series working papers no. 526. University of Oxford, Department of Economics, 2011.

[13] M. Iwamoto \& K. Nabeshima "Can FDI promote export diversification and sophistication of host countries? Dynamic panel system GMM analysis" IDE Discussion Paper No. 347, 2012.

[14] E. Weldemicael "Determinants of export sophistication. University of Melbourne: Mimeo, 2012

[15] B. Xu \& J.Y. Lu "Foreign direct investment, processing trade, and the sophistication of China's export" China Economic Review, 20(3), 2009, 425-439.

[16] S. Zhu \& X. Fu "Drivers of export upgrading" World Development, 51, 2013, pp.221-233

[17] S. Lall, J. Weiss, J.K. Zhang "The "sophistication" of export: A new trade measure" World Development, 34(2), 2006, pp. 222-237.

[18] P.K. Schoot "The relative sophistication of Chinese exports" Economic Policy, 1, 2008, pp. 5-49.

[19] A. Amighini \& M. Sanfilippo "Impact of south-south FDI and trade on the export upgrading of African economies" World Development, 64, 2014, pp. 1-17.

[20] P. Lectard \& E. Rougier "Can developing countries gain from defying comparative advatage? Distance to comparative advantage, export diversifivation and sophistication, and the dynamics of specialization" World Development 102 (2018) 90-110. 